\title{
The problem of understanding and interpretation of African philosophy
}

\author{
E.S.-F. Chukwujekwu \\ RUDN University \\ Miklukho-Maklaya Str., 6, Moscow, Russian Federation, 117198

\begin{abstract}
Проблема понимания
и интерпретации африканской философии
\end{abstract} \\ Е.С.-Ф. Чуквуджекву \\ Российский университет дружбы народов \\ ул. Миклухо-Маклая, 6, Москва, Российская Федерачия, 117198
}

\begin{abstract}
This article is devoted to the problem of interpretation and understanding of African philosophy as a phenomenon of intercultural communication. It is a question of the presence of stereotypes in perception and assessments of African philosophy: from the assertion of its interiority and non-philosophical character to the propaganda of its primacy in the whole of world philosophy as the theorized core of spiritual life. The author also indentified the significant obstacle in the study of African philosophy and understanding of its status in the history of world philosophy. Also the article touched the importance of African revival, and the key factors to its revival, the idea of Afrocentrism was also been mentioned as the key solution for the African revival. In this work, ethnophilosophy is further considered as the source of the whole philosophy of Africa. Attention is also paid to the problem of misunderstanding and misinterpretation of African philosophy and culture in the framework of world or universal philosophy and science. Also in the article, issue of searching for African identity is being raised, the ideas and impacts of some African thinkers, also socio-political concepts such as Pan-Africanism, Negritude, African socialism, African humanism, Afrocentrism and others, which had a serious impact on African socio-political life were also identified. The diversity of ethnic cultures, and its roles in the black continent were mentioned, and as well, emphasis on ethical issues, religions representations and superstitions.
\end{abstract}

Keywords: African philosophy, ethnophilosophy, ethnos, subethnos, identity, stereotypes, spiritual live

Chukwujekwu E.S.-F., 2019

This work is licensed under a Creative Commons Attribution 4.0 International License https://creativecommons.org/licenses/by/4.0/ 


\section{Article history:}

The article was submitted on 25.07.2019

The article was accepted on 22.10.2019

For citation: Chukwujekwu E.S.-F. The problem of understanding and interpretation of African philosophy. RUDN Journal of Philosophy. 2020; 24 (1): 134-142. DOI: 10.22363/23132302-2020-24-1-134-142

Статья посвящена проблеме интерпретации и понимания африканской философии как феномена межкультурной коммуникации. Поднимается вопрос о наличии стереотипов в восприятии и оценке африканской философии: от утверждения ее “внутреннего" и нефилософского характера до пропаганды первенства африканской философии во всей мировой философии как теоретического ядра духовной жизни. Автор также отметил значительное препятствие в изучении африканской философии и понимании ее статуса в истории мировой философии. Статья затронула важность африканского возрождения, ключевые факторы, идея афроцентризма была упомянута в качестве ключевого решения вопроса африканского возрождения. В данной работе этнофилософия рассматривается как источник всей философии Африки. Внимание также уделено проблеме непонимания и неверного толкования африканской философии и культуры в рамках мировой или универсальной философии и науки. Помимо этого, в статье выделена проблема поиска африканской идентичности. Кроме того, рассмотрены идеи и влияние некоторых африканских мыслителей и социально-политических концепций, таких как панафриканизм, негритюд, африканский социализм, африканский гуманизм, Убунту, афроцентризм и других, которые имели серьезное влияние на африканскую общественно-политическую жизнь. В работе затронут вопрос разнообразия этнических культур и его роли на черном континенте, а также сделан акцент на рассмотрение этических проблем, представление религий и суеверий.

Ключевые слова: африканская философия, этнофилософия, этнос, субэтнос, идентичность, стереотипы, духовная жизнь

\section{История статьи:}

Статья поступила 25.07.2019

Статья принята к публикации 22.10.2019

Для цитирования: Чуквуджекву E.C.-Ф. Проблема понимания и интерпретации африканской философии // Вестник Российского университета дружбы народов. Серия: Философия. 2020. T. 24. No 1. C. 134-142. DOI: 10.22363/2313-2302-2020-24-1-134-142

\section{Introduction}

African philosophy as a phenomenon of intercultural communication. It is a question of the presence of stereotypes in perception and assessments of African philosophy: from the assertion of its interiority and non-philosophical character to the propaganda of its primacy in the whole of world philosophy as the theorized core of spiritual life. Major obstacle in the study of African philosophy and understanding of its status in the history of world philosophy is the stereotypical view of it as an eclectic mixture of popular worldviews, and therefore as a pseudo-philosophy. However, this stereotype is generated by the dominance of a Western, classical, philosophizing image, the foundations of which were laid by Socrates, Plato 
and Aristotle, and brought to their logical conclusion by F. Bacon, J. Locke, R. Descartes, G. Leibniz and B. Spinoza, as well as I. Kant and G. Hegel. The classical paradigm of philosophizing involves a clear structuring of philosophical works into sections: ontology, ethics, epistemology, social philosophy, etc. Thus, the concept of "African philosophy" is not a self-referential sign that does not refer to anything in reality. Its content contains a complex of worldview opinions, ideas, concepts, ideas, principles, expressing a feeling and understanding of the world by carriers of a black African identity.

\section{Stereotypes in the perception of African philosophy in European culture}

A significant obstacle in the study of African philosophy and understanding of its status in the history of world philosophy is the stereotypical view of it as an eclectic mixture of popular worldviews, and therefore as a pseudo-philosophy. However, this stereotype is generated by the dominance of a Western, classical, philosophizing image, the foundations of which were laid by Socrates, Plato and Aristotle, and brought to their logical conclusion by F. Bacon, J. Locke, R. Descartes, G. Leibniz and B. Spinoza, as well as I. Kant and G. Hegel. The classical paradigm of philosophizing involves a clear structuring of philosophical works into sections: ontology, ethics, epistemology, social philosophy, etc. In addition, there was a clear distinction of philosophy according to the criterion of solving the fundamental issue of philosophy. From the ontological side: to materialism, idealism and dualism, and from the epistemological - to epistemological optimism and agnosticism. One more criterion of philosophical classics should be highlighted - the prevalence of the rational over the irrational, the postulation of reason as the leading principle of knowledge. Philosophy is often associated with the cleansing of the human mind of superstitions, religious prejudices, myths and logically unreasonable, generated by everyday experience, judgments that make up the so-called folk philosophy.

But even in Western European philosophy in its classical development in the 19th century, a non-classical paradigm begins to compete, based on the rejection of rationalism in favor of irrationalism, an appeal to the sources of worldview that lie in myths and folklore, traditional values and beliefs. Western intellectuals turn to the wisdom of the East: Hinduism, Buddhism, Taoism and other philosophical and non-traditional religious teachings. A similar surge of irrationalism is taking place against the backdrop of a growing interest in occultism, magic, and similar extrascientific forms of knowledge.

We can say that the classical paradigm of Western philosophy focuses on its understanding as a special science, which means building it according to the criteria of scientific knowledge, with a number of exceptions, the most obvious of which is the lack of a systemic organized empiricism. In the non-classical paradigm, philosophy can come closer to art, mythology, but not to the scientist ideals of science. Therefore, the totality of African collective world views in this perspective also, in our opinion, appears as philosophical knowledge. Moreover, the work of African thinkers who own and use Western philosophical tools to solve specifically African 
philosophical problems, of which central is the search for their own identity, can rightly be called philosophy. Thus, the concept of "African philosophy" is not a self-referential sign that does not refer to anything in reality. Its content contains a complex of worldview opinions, ideas, concepts, ideas, principles, expressing a feeling and understanding of the world by carriers of a black African identity.

Stereotypes in understanding African philosophy, and above all its pessimistic perception, in our opinion, express a broader in scope coverage problem of disharmony of interracial and interethnic relations. The relations of the European colonialists with the indigenous population of Africa have many tragic moments reflected in the modern globalized world, but, despite this, they do not exclude ethnic and racial hostility, manifestations of nationalism and chauvinism, which was initiated by the inhabitants of the Western, "civilized" world and taken up by individual representatives other ethnic and racial groups, including Africans. The latter was an extreme option to counter the entire spectrum of negative manifestations of colonization and globalization.

\section{Ethnophilosophy as an original phenomenon of African spiritual culture}

African philosophy in its origins without the colonial raid of European rationalism is more a folk philosophy, part of the life of representatives of traditional African culture than an academic philosophy that ripens in the minds of professional philosophers and settles in articles, monographs, theses of scientific conferences and voluminous treatises. If philosophy is regarded as an academic discipline, then the concept of "African philosophy" is empty, without real content. And if philosophy is understood more broadly, approximately in the same meaning in which N. A. Berdyaev used the word "philosophizing", then African philosophy as a term (meaning) and as a special layer of worldview belonging to the bearers of the African mentality (meaning) receive their legitimation. It was this layer of worldly wisdom, crystallized in myths, traditions, moral norms, principles and ideals, the system-forming among which is the Ubuntu principle, that became the subject of rational reflection of African humanities scholars and philosophers and became known as ethnophilosophy. Ubuntu means humanity, recognition of the dignity of each person. This idea is promising in terms of spiritual and moral development as an African society, which confirms not only its vitality, but also its significance. In myth-religious beliefs, often mixed with protophilosophical and philosophical constructs, many peoples meet the ideas of goodness and humanity as the most important grounds for the harmonious coexistence of people.

Richard Bell points to the African way of thinking and worldview, which differs from the European way of seeing, called ethnophilosophy [1. P. 204]. Ethnophilosophy can be reduced to three main points:

1. The term "African philosophy" has a real content, including the borderline principles of world understanding that underlie African cultures and civilizations. To reveal this content of the spiritual life of the peoples of the African continent, classical philosophical methods developed by European thinkers are needed. 
2. African philosophy consists mainly of ontological representations, in which interacting and hierarchically ordered into a single system of force are recognized as the foundation of being, which has substantial significance.

3. Ontology is the source of ethnophilosophical anthropology, since the main point of mutual intersection of natural forces is.

African philosophy in the 20th century is for the most part a metaphilosophy that includes the following questions:

1. Where is Africa (not only in terms of geographical boundaries, but also in the spiritual and cultural framework of African philosophy, how much its problems, thinking style, and elements of culture affect other continents)?

2. Who is an African - a question of identity. Often this question focuses on the concept of ubuntu.

3. The ratio of colonial African philosophy and traditional.

\section{Misunderstanding of the African worldview as a hindrance to the integration of African and Western philosophical paradigms}

African philosophy as a phenomenon of world metaphysics has conflicting assessments, the polar of which are, on the one hand, its placement in a group of pseudophilosophy, the belief in its inferiority and hopeless backwardness due to the archaic nature of African culture [2. P. 68], and on the other hand, recognition of the status of the core of African spiritual culture by African philosophy. The latter is assessed as unfairly devalued in its importance of priority and meaningfully veiled by the European colonialists of importance. So Mabogo P. speaks of two main areas: afropessimistic and progressive liberation [3. P. 75].

Afropessimism considers the policy of a return to basics to regression, a return to the "natural state of the war of all against all." In this state, there was and cannot be law, morality, civil society. Afro-pessimists, for example, Hitchens C. Johnson P., Kaplan R., described a similar state in pre-colonial Africa, which served as a significant argument for justifying the European colonization considered as a civilizational mission, which brought to Africa the foundations of modern morality, culture, law, civil society $[4 ; 5 ; 6 ; 7]$.

If colonial rule ceases, this will mean the end of modernization, and the established African regimes will create many risks (in many cases embodied in their worst cases) of regression, that is, a rollback to the pre-colonial "natural state" [7. P. 72].

Such an opinion, according to Mabogo P., expresses "Western distorted ideas about Africa and Africans, due to ideological and political motives and the desire to stop and inhibit transformative practice" [8. P. 65].

The opposite pessimistic opinion (with which Mabogo agrees) gives an assessment of the concept of African revival as spiritual decolonization, the purpose of which is to restore and reconstruct African identity based on modern requirements. This opinion is based on an optimistic assessment of the potential of Africa and, con- 
sequently, African philosophy, which has strong ethno-cultural foundations. To perpetuate their dominance, the colonialists, according to P. Mabogo, "sought to enslave the African mind and destroy the African soul" [8. P. 69].

In view of this circumstance, the African revival is called for the formation of a "new mindset among Africans."

The African revival is not a "return" to the primordial "truth" or the undistorted "African primary principle", it is something that enables the activation of the vital and creative forces of Africans to transform their lives [8. P. 75].

An important factor in the African revival is the appeal to African history and its rethinking, the restoration of historical consciousness, the identification of specific features of African civilization, its values, creative achievements, political and social norms and institutions that have not lost their relevance in modern days.

The golden mean here will be recognition based on the principle of cultural relativism of the originality of the African worldview, spiritual culture and philosophy as its theorized core. If we differentiate philosophy as a part of world spiritual culture by ethnic groups, or civilizations, or by continents into Western, Eastern and Russian, then the closest to the origins to African will be Eastern, or more precisely, Muslim philosophy, since the vaccination of Western European academic philosophy with it rationalism, mechanism, utilitarianism, historical objectivism was done later - after the colonization of the African continent. But the competition between the Christian West and the Muslim East for the primacy in influencing the spiritual and theoretical life of Africa is meaningless, given that the first and the second rely heavily on the achievements of ancient Greek intellectuals, primarily Plato and Aristotle.

An interesting solution to this problem, in our opinion, is Conscienceism (philosophy of consciousness") Kwame Nkrumah, which synthesizes Marxist philosophy, a number of Christian and African traditional concepts, as well as communism [2. P. 68]. The philosophy of consensibilityism postulates the need for awareness of African identity and its inherent humanistic traditions based on the best achievements of Western, Arab and Euro-Christian cultures. It is the achievement of such a synthesis that will allow African culture to integrate into the world system. The philosophy of consciousness quite successfully combines all the origins of the modern African worldview - ethnophilosophy, Arab intellectual trends and a number of philosophical concepts of the West, primarily Marxism.

Julius Nyerere develops a socialist concept, justifying its conformity to traditional African culture with its communism, that is, community $[9 ; 10]$. The ideas of equality, distributive solidarity are related African social and philosophical thought with Marxism. It was Marx K. who gave a justified critical analysis of a market economy based on capital. Many of the shortcomings of capitalism inherent in high market efficiency societies are associated primarily with the inevitability of social inequality, poverty, unemployment and hopeless poverty, and inhuman competition. Even in a seemingly prosperous USA, the flaws of the social sphere are now and again revealed, which is reflected in journalistic investigations, documentary 
cinema, feature films and books. It is enough to recall the theory of deviant behavior of R. Merton, where this phenomenon is explained through the contradiction between the declared value of material success and the lack of resources for its achievement by all US citizens.

\section{The problem of searching for African identity against the background of cultural and linguistic pluralism}

The search for African identity, its roots and specificity intensified markedly with the acquisition of independence by African countries. The ideas of the originality of African civilization initiated a number of socio-political currents of such concepts as Pan-Africanism, Negritude, African socialism, African humanism, Afrocentrism and others, which had a serious impact on African socio-political life. A new powerful incentive to intensify the efforts of African scientists and politicians in this direction was the idea of the African Renaissance described above. The emergence of many socio-political concepts can be called the second important trend in the development of African philosophy in the modern world.

The Nigerian philosopher Theophilus Okere adopted a hermeneutic approach, as it allows to preserve the authenticity of the ethno-philosophical heritage of Africa, to reveal the true meanings and meaning of texts of traditional culture, to overcome the bias with which the Westernized philosophers belonged to the intellectual heritage of the African continent [11. P. 61]. He accepts Gadamer's ideas regarding the social and cultural context. In other words, to be truly African, philosophers must be directly related to the culture in which they are located [11. P. 62].

In Western anthropology, a tradition-based culture is often portrayed as devoid of change or development, because it is also devoid of critical or reactive thinking. It is said that beliefs and customs inherited from the "ancestors" are preserved unchanged in the present, and then passed on to the next generation with the understanding that they will be preserved and respected in a similar way. Therefore, knowledge does not progress, and those who dare to challenge the established Traditions jeopardize their own welfare. Faith in Fate is portrayed as an encouragement of rather strict in relation to man and underlying the entire universe, especially nature, and therefore the existence of man, transcendental forces.

A severe manifestation of determinism, according to which it is believed that, what will be, will be. They say that this also hinders the development of independent or individual initiative [11. P. 63]. However, according to Okere, following the natural course of things allows a person to achieve harmony in interaction with the world and in accepting himself and his position. A similar interpretation of the relationship between freedom and causality can be called fatalism, that is, belief in blind fate, and in natural science terminology — determinism. Similar views are characteristic of most traditional cultures.

The search for African identity is complicated by sub-ethnic differentiation of the population of the African continent. Despite the common racial affiliation and 
ethnonym "African", each sub-African community is characterized by a specific language, tradition, historical, memory, religious beliefs, worldview. To find a common that can serve to characterize all Africans, among the bright variety of territorial-subethnic groups, is an important task in solving this problem. However, the Africans are united by the fact that, according to the apt remark of Sengor, they perceive the world as something whole, and themselves as part of the world, unlike Europeans, who do not penetrate the universe, and are content only with its sides that bring them real economic benefits [12. P. 72].

Some African philosophers (J. Mbiti, K.O. Ovomoel, L. Sengor, A. Kagame, P. Tempels), see the philosophical foundation in the traditional worldview of Africans. A. Cabral, K. Krumai, J. Nyerere, F. Fanon and L. Senghor consider philosophy in Africa a political philosophy inspired by colonialism and anti-colonialism. Such African philosophers as P. Bodunrin, K. O. Oruka, Viredou, P. Huntunti and S. Kwame adhere to universalism and particularism. For example, S. Kwame argues that the analytical methodology of Western philosophy is the opposite of the philosophical tradition of Africa [13. P. 40-41].

African intellectuals see their mission in the destruction, dismantling of existing systems of economic, political and ideological control. "“These paradoxes," Mudimbe believes, "show that we are dealing with ideology. Modern African thought is basically a product of the West" [14. P. 209].

"The very idea of Africa," he emphasizes, "was formed in the West and in the course of its centuries-old evolution generated various African discourses that, although they do not provide a real, adequate idea of the essence of the African worldview, nevertheless firmly established Africa as an object of scientific knowledge" [15. P. 212]. You can not agree with this opinion, since African culture and African worldview are unique phenomena that have no analogues in the whole world. The diversity of ethnic cultures, which makes it difficult to systematize the worldview of the black continent into a single system, when examined in more detail, forms a symphonic unity that combines centuries-old wisdom in the perception and understanding of the world and a person's place in it.

\section{Conclusion}

Thus, understanding of African philosophy constitutes a significant problem of metaphysics, depends of revealing the place of the theoretical core of the worldview of the inhabitants of the African continent in world philosophy, as well as clarification of the metaphysical foundations of African ethnic consciousness, substantiation of its originality and uniqueness, on the one hand, and the potential for productive interaction with other continental layers of world philosophy and their mutual enrichment. As for the Russian philosophical environment, here the philosophy of Africa is not widely popular as a subject of study, it is considered as something exotic and ambiguous. Although, with more detailed attention, semantic parallels with Russian philosophy are revealed, among which, for example, the similarity of the Ubuntu principle and Russian communitarianism and humanitarianism [16]. Humanity is an important element of Ubuntu, which is actually manifested in 
mutual assistance, which was also characteristic of traditions of mutual assistance in within rural communities, which was reflected in philosophy in terms of collegiality), emphasis on ethical issues, reliance on folk philosophy and folk psychology, mixed with folk mythological religions representations and superstitions.

\section{References}

[1] Bell RH. Understanding African Philosophy. N.Y., London: Routledge, 2002. P. 204

[2] Nkrumah K. Consciencism: Philosophy and Ideology for De-Colonization. 1964. P. 68.

[3] More MP. African Renaissance: the politics of return. African Journal of Political Science. 2002;7(2):65-80.

[4] Xinhua News Agency. "France: Creditors Should Do More for Africa's Debt Problem." Paris, March 27, 1988. Item no. 0327019.

[5] Hitchens Ch. "Africa without Pity." Vanity Fair. (November 1994): 43-52.

[6] [6] Johnson P. "Colonialism's Back — and Not a Moment Too Soon.” New York Times Magazine (April 18, 1993): 22.

[7] Kaplan R. "The Coming Anarchy.” Atlantic Monthly (February 1994): 44-76.

[8] More MP. African Renaissance: the politics of return. African Journal of Political Science. 2002;7(2):65-80.

[9] Nyerere JK. Ujamaa: Essays on Socialism. N.Y.: Oxford University Press; 1968;

[10] Nyerere JK. Ujamaa: The basis of African Socialism. Oxford University Press, 1968

[11] Bruce BJ. Philosophy in an African Place. Lexington Books; 2009.

[12] Senghor LS. On African Socialism. N.Y.: Praeger, 1964. P. 94, 72.

[13] Mikhalina OA. African philosophy of education in search of meaning. RUDN Journal of Philosophy. 2010;(3):39-46.

[14] Mudimbe VY. The Invention of Africa: Gnosis, philosophy a. the order of knowledge. Indiana univ. press; 1988. XII.

[15] Mudimbe VY. The idea of Africa. Indiana polls: Indiana univ. press; L.: Currey, 1994. XIX. 235 p.

[16] Chistyakova OV. Philosophical-religious Legacy as the Basis for the National Identity and Humanitarian Education of Modern Russia. Proceedings of the 2nd International Conference on Culture, Education and Economic Development of Modern Society (ICCESE 2018). Advances in Social Science, Education and Humanities Research. Moscow, Russia, March 01—03, 2018. Paris, Atlantis Press, 2018. P. 1279—1283.

\section{About the author:}

Chukwujekwu Ejike Sam-Festus — postgraduate student, RUDN University (e-mail: chukvudzhekvu-es@rudn.ru).

\section{Сведения об авторе:}

Чуквуджекву Еджике Сэм-Фестус - аспирант кафедры истории философии Российского университета дружбы народов (e-mail: chukvudzhekvu-es@rudn.ru). 